\title{
Headache as a symptom of Multiple Sclerosis
}

\author{
T Kalamatas ${ }^{*}$, N Protopapas, E Vasiliadis ${ }^{*}$, P Karanasiou, K Karageorgiou \\ From The European Headache and Migraine Trust International Congress \\ London, UK. 20-23 September 2012
}

\section{Introduction}

Our aim was to investigate the prevalence of headache in Multiple Sclerosis (MS). We studied data from our department's day clinic files of MS patients. The associations between headache characteristics and clinical features of MS were investigated.

\section{Purpose/background/objectives}

Our main goal is to study the comorbidity of headache and MS. We investigated possible correlations between MS clinical course and headache characteristics. Headache is a common complaint between Multiple Sclerosis (MS) patients. It has been found that headache prevalence during MS is above $50 \%$ and this is different from the percentage of the general population. There are many studies that show comorbidity of headache and MS (56.2\% 2).

\section{Methods}

We retrospectively studied demographics data from MS patients of our department's day clinic (sex, age, duration of MS, presence of headache, type of headache, number of headache attacks per year).

\section{Results}

From 144 patients, 75 (52\%) presented with symptoms of headache. $69.2 \%$ were female and $30.8 \%$ were male. $25 \%$ of the patients had headache before MS diagnosis and migraine was a symptom of $61.5 \%$ of the above mentioned patients. No statistical significant associations could be determined between duration of MS disease and the frequency, strength and duration of headache.

\section{Conclusion}

Headache with or without other neurological signs could be coexists with MS in greater frequency than the healthy population. The above outcome could be explained by some common underlining biological mechanisms.

\footnotetext{
GNA G.Gennimatas, Greece
}

\section{SpringerOpen $^{\odot}$}

(c) 2013 Kalamatas et al; licensee Springer. This is an Open Access article distributed under the terms of the Creative Commons Attribution License (http://creativecommons.org/licenses/by/2.0), which permits unrestricted use, distribution, and reproduction in any medium, provided the original work is properly cited.
Further studies are needed to clear up the mechanisms of headache co-morbidity with MS.

Published: 21 February 2013

\section{References}

1. Rolak LA, et al: Headaches and multiple sclerosis: a clinical study and review of the literature. Journal of Neurology 237(5):300-302

2. Putzki N, et al: Prevalence of migraine, tension-type headache and trigeminal neuralgia in multiple sclerosis. European Journal of Neurology 2009, 16(2):262-267.

3. D'Amico D, et al: Prevalence of primary headaches in people with multiple sclerosis. Cephalalgia 2004, 24(11):980-984.

doi:10.1186/1129-2377-14-S1-P171

Cite this article as: Kalamatas et al:: Headache as a symptom of Multiple Sclerosis. The Journal of Headache and Pain 2013 14(Suppl 1):P171.

Submit your manuscript to a SpringerOpen ${ }^{\circ}$ journal and benefit from:

- Convenient online submission

- Rigorous peer review

- Immediate publication on acceptance

- Open access: articles freely available online

- High visibility within the field

- Retaining the copyright to your article

Submit your next manuscript at $>$ springeropen.com 